\title{
Evaluating energy consumption in terms of climatic factors: A case study of Karakol residential apartments, Famagusta, North Cyprus
}

\author{
*Dr. ROKHSANEH RAHBARIANYAZD', Dr. LAYLA RASWOL ${ }^{2}$ \\ 1 \& 2 Department of Architecture, Nawroz University, Duhok, Kurdistan Region, Iraq \\ E mail: rokhsaneh.rahbarianyazd@gmail.com E mail: layla.raswol@vod.ac
}

\section{ART I CLEINFO: \\ Article history: \\ Received 23 July 2017 \\ Accepted 23 August 2017 \\ Available online 23 August 2017}

Keywords:

Residential Apartments; Energy Consumption; Climatic Factors; Famagusta.

This work is licensed under a Creative Commons Attribution NonCommercial - NoDerivs 4.0. "CC-BY-NC-ND"

\begin{abstract}
A B S T R A C T
Throughout the past few decades, research has demonstrated that climatic factors are some of the most important issues to be considered in respect of energy consumption in buildings. Climatic factors, therefore, directly influence the economic sector. In order to study the impact of climatic factors in Karakol residential buildings in terms of energy consumption, an evaluation of the studies (literature survey) effected in relevant climates, and the analysis of the existing buildings according to these studies is essential. This represents the aim of this research and the other is to present design strategies for minimizing the negative impact of climatic factors on energy demand in these buildings. To approach the research objectives, the climate of the region was initially investigated. In an attempt to evaluate some of the current housing in the Karakol district of Famagusta in terms of the climatic factors, three types of residential apartments were identified and evaluated through observation, interview, and also by the distribution and complication of qualitative and statistical questionnaires to and by the occupants of the apartments. In this paper, basic climatic problems, as a result of which lead to increased energy consumption in residential apartments in respect of heating and cooling were identified and reported.

JOURNAL OF CONTEMPORARY URBAN AFFAIRS (2018) 2(1), 45-54.
\end{abstract}

https://doi.org/10.25034/ijcua.2018.3658

Copyright (c) 2017 Journal Of Contemporary Urban Affairs. All rights reserved.

\section{Introduction}

In most societies such as United States (EIA 1 , 1999) and also India (Indraganti, 2010) the use of energy in residential buildings for heating and cooling which provides thermal comfort, is one of the highest consuming sector. Providing comfortable and adequate working conditions for occupants in buildings necessitate the need to control the climatic factors of the building.

*Corresponding Author:

Department of Architecture, Nawroz University, Duhok,

Kurdistan Region, Iraq

E-mail address: rokhsaneh.rahbarianyazd@gmail.com

\footnotetext{
${ }^{1}$ Energy Information Administration
} 
For instance, the issues of temperature control, humidity, lighting and ventilation require the utilization of energy. On the other hand, successful energy conservation is achieved by aiming for the least possible energy consumption and this will be achieved through the support and awareness of both the architect and the resident (Landsberg \& Stewart, 1980, p.3-5).

As is demonstrated by the research, energy consumption can be influenced by climatic factors such as temperature, winds, moisture or precipitation and many other factors, so these factors equally and directly have influence on the economic sector and present a major problem in residential apartment buildings, which are generally chosen by people with lower incomes, who wish to have less expensive housing, but who, in fact, because of inappropriate design features and up paying out more than in necessary for energy consumption.

Buildings are comprised of two parts: the interior and the exterior surfaces (roof, external walls, glazing, and floor). Climatic factors impact on the exterior surface of buildings and the energy transmission because of the difference temperature and also surface transmission coefficient will be done by these exterior surfaces (Landsberg \& Stewart 1980, P.16-20). In the US between the years 1973-1984, the sudden increase in energy costs attracted the attention of architects to the issue of energy management in buildings. As a result of this awareness and focus, the energy efficiency of buildings greatly improved in respect of improving the design and functioning of windows, roof and wall insulation, and heating and cooling systems, etc. (Galloway, 2004, p.182).

As a result using appropriate materials in external walls and design methods for the existing climatic condition factors is essential. A literature survey on the residential buildings in the relevant climatic condition was carried out to identify typical designs developed in respect of climate. The construction of buildings as per climatic factors is an excellent case for addressing the issue of energy consumption efficiency.

\section{Methodology}

Qualitative and qualitative approach methods have been used in this research and the techniques applied are those of personal observation, in depth interviews, administered qualitative and statistical questionnaires with closed-end questions, review of related literature, and internet sources.
In general the most significant important factors that impact on energy consumption are: location and climate data of the building, orientation of the building, installed materials, building design and the selecting of the technical systems (Leskovar, \& Premrov, 2011).

This study attempts to survey some of these items due to literature review and as aforementioned three residential apartments have been identified in the Karakol district which is shown in figure 2. Analyzes have been done through interviews and questionnaire with the occupants of the Karakol district.

\section{Climate zone survey}

The district of Karakol in Famagusta has a transition climate, which lies between a composite and a hot, humid climate, however because of proximity to the sea it is called hothumid climate (Özdeniz and Hançer, 2005; Hançer, 2005).

\section{Literature survey of the relevant climate on buildings}

In order to evaluate the impact of climatic factors on residential buildings in Karakol_ in terms of energy consumption, it is necessary to survey the literature review and analyze the buildings in this area.

\subsection{Orientation}

Oktay's (2002) evaluation of the vernacular housing in Northern Cyprus, which were adapted for the hot and humid climate, offered useful suggestions such as orienting living spaces towards the south using light colors on the external walls and roofs in order to reflect the sunshine, using a narrow plan with opposite windows in order to create cross-ventilation and thus creating and designing more sustainable conditions for new buildings.

According to Givoni (1994) creating cross ventilation in buildings with two openings in different walls (one of which is facing to the wind direction) for all the rooms in a hot-humid climate is very useful. Providing these openings for each room in buildings especially apartment buildings, but ensuring the free flow of air between all rooms in the buildings is essential.

Aksugur (1996) study examined four cities in Cyprus with four different climates, he and also Thomas (2002, p. 156-158) in his book made some recommendations for minimizing the energy usage in buildings in a hot-humid climate. Buildings in this climate would be oriented with 
the longest sides toward north and south with openings for ventilation and they would also have walls to provide shade and external opening by using wide eaves and deep verandas. The ventilation of roof space for minimizing the high solar radiation was also included in their recommendations.

Hot and humid climates usually require air conditioning in order to provide thermal comfort. This process requires energy. Energy performance in buildings refers to the ability of a building to function with minimum energy utilization. This thermal comfort could be improved by creating sufficient microclimate strategies in the surrounding area of the buildings (Zain, Taib, \& Shah Baki, 2007).

Acceptable air speed depends on the environment temperature and humidity. At a temperature below $33 e^{\circ} \mathrm{C}$, an increase in air speed will decrease the heat sensation (Givoni, 1998, p.17). According to the data for Famagusta's climate (Aksugur, 1996) which is shown in figure 1, the air speed process will make the residential spaces in Karakol comfortable.

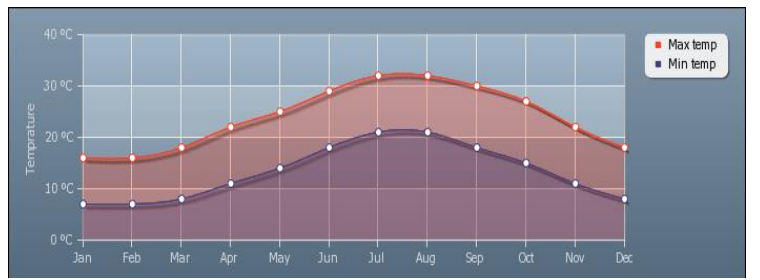

Figure 1. Average minimum and maximum temperatures for Famagusta over the year (retrieved from url1, 01 thapril, 2015).

\subsection{Materials}

\subsubsection{Roof and floor}

The Ozdeniz \& Hançer (2005) Study examined 14 different types of roof construction, which is used in the hot-humid climate of Cyprus in terms of energy loss and gain. The sloped timber roof with ventilated attic space and inner thermal insulation materials proved to be the best choice for this climate to avoid building up heat in summer.

For the hot and humid climate minimizing the conductive heat gain in the summer (Aksugur, 1996) by using a ventilated double roof with aluminum foil which is attached above the ceiling is essential (Eco-housing mainstreaming, 2009, p. 14; Dinsev \& Mohd, 2004). In this respect, the roofs with thermal insulation performed the most efficiently.
Coch's (1998) study investigated several typologies of the vernacular dwelling depending on the climate. One such evaluation was carried out in a hot and humid climate. In this climate the roofs are broken constructed so that the hotter air is held at the top along with and an opening for circulating the air in order to avoid_ overheating. These steep slopes_also provide useful drainage for the frequent rains. The floors are raised to better receive the breezes and are permeable to the air, so in this way theventilation facility of the whole envelope of the house is complete.

\subsubsection{Windows}

Windows and other glazed areas are weak in respect of the transfer of unwanted heat. The resistance of the glazing material, the number of glazed panels, the air spaces between, and the design and detail of the frame affect the insulation value of the glazing unit. (Watson \& Labs, 1983, p.171).

Windows, as a significant part of a building's external surface can heat spaces through the glass: the best glass_ is transparent so that the light can reflect the heat. The best reduction of glassing in solar gain is Tri-pane-plate $130 \%$ reduction of solar gain) compared with plate glass, double pane-ordinary and double paneplate (Landsberg \& Stewart, 1980, p.30-31; Galloway, 2004, p.21).

Aksugur's (1996) suggestion for hot climates was double-glazing with wooden frames or aluminum frames with thermal break type.

The thermal quality of different types of glass varies; low E double glazing is the standard type and triple glazing is more commonly used for residential buildings. However the perfect glazing systems are those that can react flexibly to the changing incoming radiation quantities and interior conditions by using a movable louvre between the panes of the double or triple glazing units (Hegger et al., 2008 p. 91-97).

\subsubsection{Shading}

The outcomes of the shading study (Aksugur, 1996; Galloway, 2004, p.19-25) shows that rooms with windows which are located on the south side of a building become hot in summer. In order to combat this problem a permanent awing could attached to the building for shade. 


\subsubsection{External walls}

Hot climates such as Cyprus are excellent for providing passive solar heating (Lapithis, 2004) but a balance is required between heating and cooling in order to prevent overheating and discomfort in summer. In order to achieve this elements of such a dwelling are double- paned glass on the south side where the living spaces are located, the use of mass material such as concrete, brick and stone for storing up the sun's energy as thermal mass, using windows and doors or maybe fans for convicting the heat throughout the house. (North Carolina Department of Commerce, 1999, p.5-6; Givoni, 1992). Thermal mass just stores the heat and does not work as an insulating material (Ecohousing Mainstreaming, 2009, p.3).

\subsubsection{Insulation}

Thermal insulation in buildings not only reduces the need for air-conditioning, but also reduces the annual energy cost. In all climates walls and roofs must be insulated in order to reduce the heat transmission. Moisture has negative effects on the insulating efficiency of material (Smith, 2005, p.69). Due to the negative impact of moisture on thermal insulation over time it must be controlled in buildings with the use of ventilation or other means (Al-Homoud, 2005).

Roofs provide the main heating for living spaces as a result of radiation. In order to reduce overheating in summer the roof must be protected by the appropriate insulation to provide the desired U-value (thermal conductivity) (Eco-housing Mainstreaming, 2009, p.18).

\section{Data Collection, Sample Size, and Analysis}

Random sampling techniques were adopted for this study, in the form of three apartments with two, four and six division of floors (Figure 2) and the occupants were interviewed to obtain their opinion about their energy usage and its cost. These apartments were analyzed in respect of their orientations, their spatial arrangements, their dimensions, surface finishes, construction materials used, and types of glazing.

A statistical questionnaire survey was administered to 100 inhabitants in various apartments within the Karakol district. The questionnaires were completed by the respondents within a specified period and collected. Out of 100 questionnaires 80 were retrieved from the respondents.

Therefore, this data analysis will make use of 80 questionnaires. The data contained in the questionnaires was used to guide the researcher in his findings and to support accurate results.

\section{Data Collection, Sample Size, and Analysis}

Random sampling techniques were adopted for this study, in the form of three apartments with two, four and six division of floors (Figure 2) and the occupants were interviewed to obtain their opinion about their energy usage and its cost. These apartments were analyzed in respect of their orientations, their spatial arrangements, their dimensions, surface finishes, construction materials used, and types of glazing.

A statistical questionnaire survey was administered to 100 inhabitants in various apartments within the Karakol district. The questionnaires were completed by the respondents within a specified period and collected. Out of 100 questionnaires 80 were retrieved from the respondents.

Therefore, this data analysis will make use of 80 questionnaires. The data contained in the questionnaires was used to guide the researcher in his findings and to support accurate results. 


\subsection{Evaluation of three residential apartments}
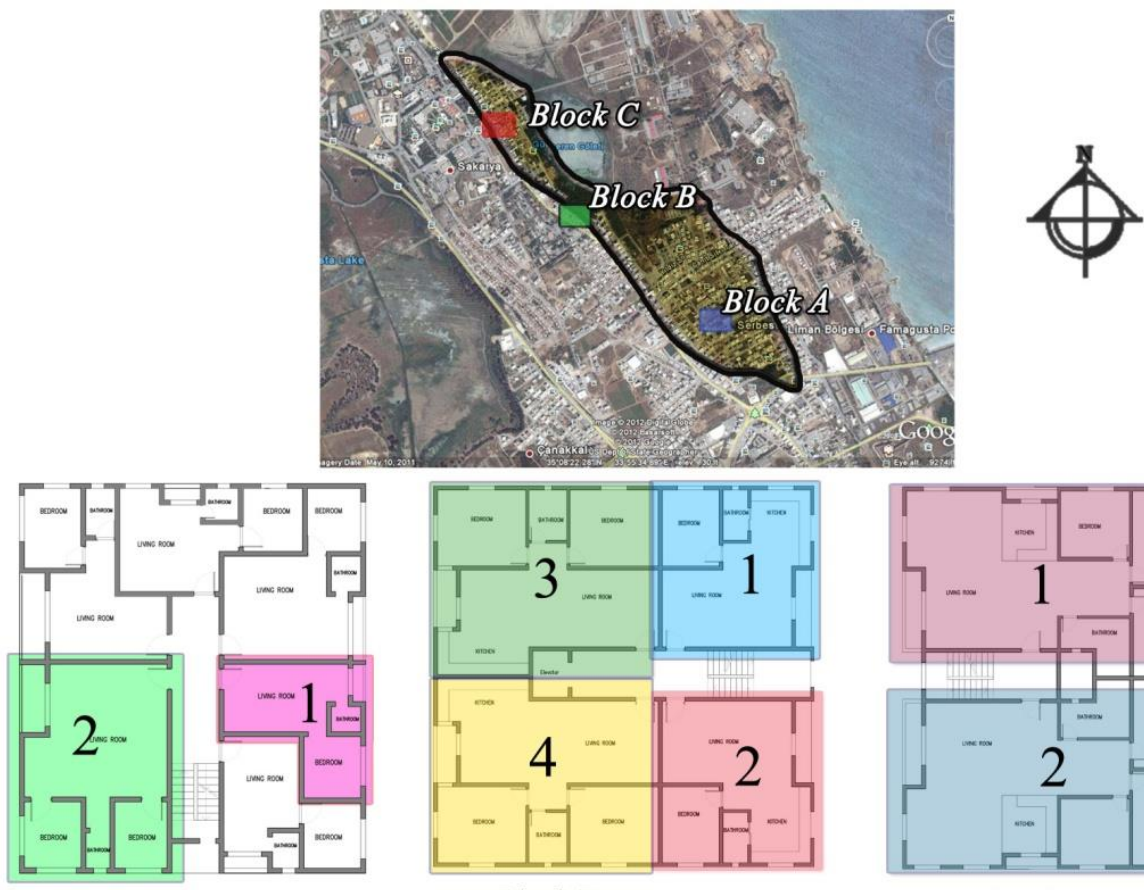

Block C

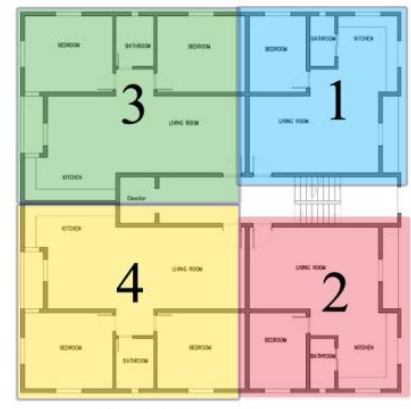

Block B

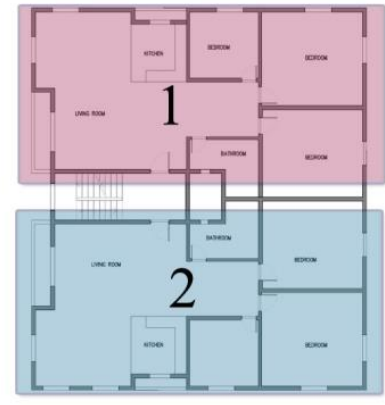

Block A

Figure 2. Position of three residential apartment in Karakol area for surveying (Retrieved from URL 2, 13 thmarch, 2016), and also plans of three sample apartments; from left to right. Uzun apartment Merkez, Uzun apartment 10, Muçize apartment (drawn by author).

\subsubsection{Orientation}

Table 1 demonstrates the features of selective units in Uzun apartment 10 and Muçize apartments (Figure 3 \& 4).

An analysis of the electric bills over a 4 month period (January, February, March, April) and by conducting personal interviews with the occupants of the buildings within the -same area and with the same number of occupants showed that the occupants located on the North and North-East sides of these buildings consumed more energy, than the occupants or users on the South and South- East side of the building. This means, of course, that they pay more for their energy in winter. In addition, photographs of the exteriors were also recorded, as shown in Figure $3 \& 4$.

Table 1. Feature of selective units (area, orientation and also number in household).

\begin{tabular}{|l|c|c|l|l|}
\cline { 2 - 5 } \multicolumn{1}{c|}{} & \multicolumn{1}{c|}{ Area $\mathbf{~ m}^{\mathbf{2}}$} & $\begin{array}{l}\text { Number } \\
\text { household }\end{array}$ & $\begin{array}{l}\text { Orientation of the } \\
\text { units }\end{array}$ & $\begin{array}{l}\text { Position of living } \\
\text { room in each unit }\end{array}$ \\
\hline Block A, Unit 1 & 150 & 3 & North & North-West \\
\hline Block A, Unit 2 & 150 & 2 & South & South-West \\
\hline Block B, Unit 1 & 60 & 2 & North-East & East \\
\hline Block B, Unit 2 & 60 & 3 & South-East & East \\
\hline Block B, Unit 3 & 80 & 3 & North-West & West \\
\hline Block B, Unit 4 & 80 & South-West & West \\
\hline
\end{tabular}



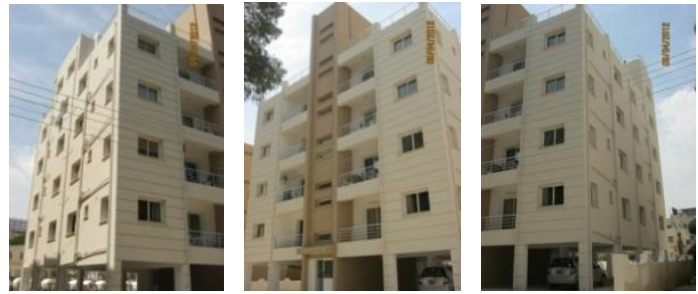

Figure 3. From right to left. North, South and East facade of the Uzun apartment 10 (research's field study, taken by author, 2016).

\subsubsection{Ventilation}

By analyzing the selective plan of Karakol buildings, it was observed that the prevailing wind in summer, which comes from the South cannot reach some of the units, therefore these buildings become overheated in summer. As is shown in Figure 5 block $C$, unit 1 does not have opposite

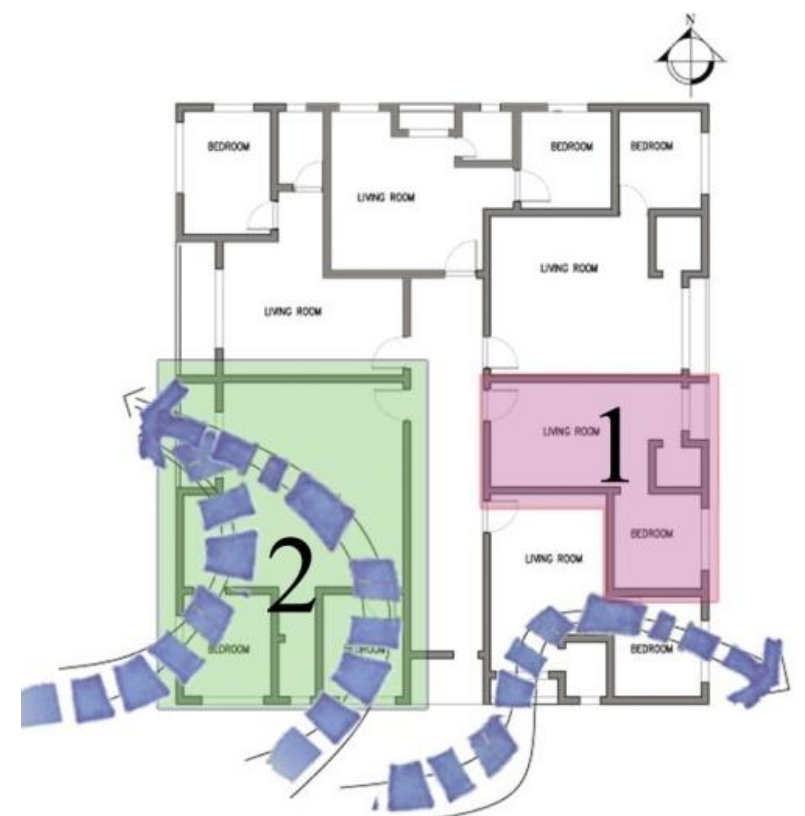

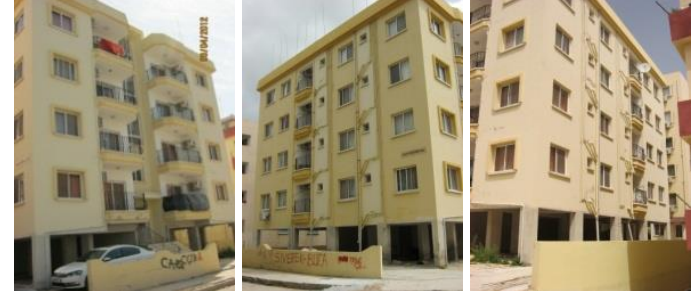

Figure 4. From left to right. West, North, South façade of the Muçize apartment (research's field study, taken by author, 2016).

windows so the air cannot circulate in the space especially in living room and during the summer the space becomes overheated and the occupants are required use the air conditioning during May and June, when it should not normally be necessary to do so.

Figure 5. Movement of wind in block C, \& block B.

\subsection{Evaluation of Karakol residential apartments}

\subsubsection{Glazing type}

From the research study as indicated in the pie chart (Figure 6), it was observed that $75 \%$ of the glazed units in the Karakol district are single glazing; this drastically increases the energy consumption as energy escapes from the space during heating or cooling (Landsberg \& Stewart 1980, p.31). This factor will increase the cost and monthly energy consumption of these buildings.

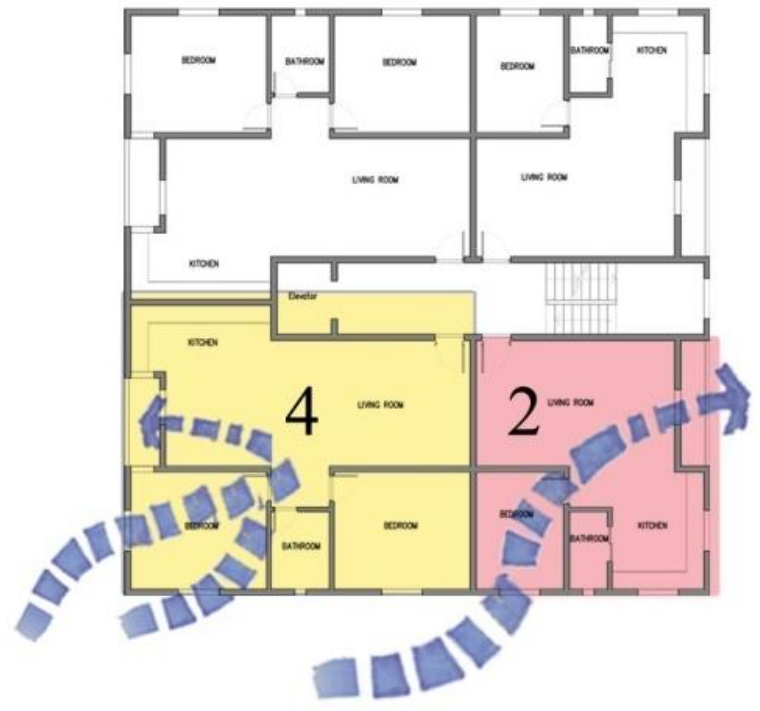

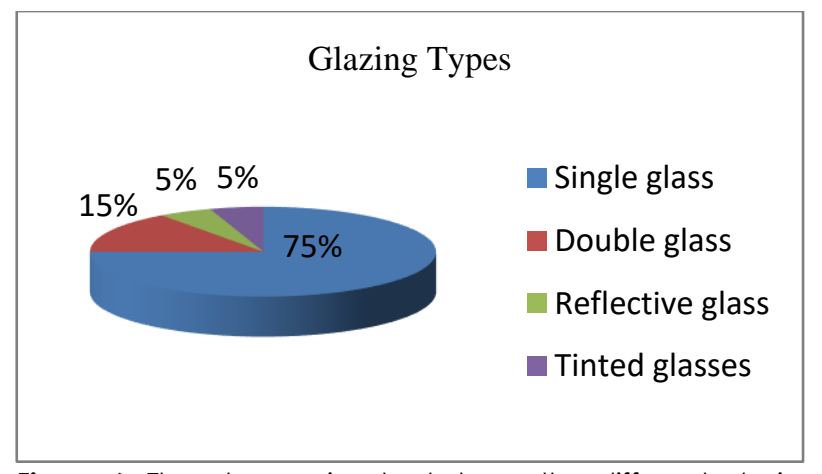

Figure 6. The above pie chart shows the different glazing types in Karakol residential buildings. 


\subsubsection{External wall material}

As it shown in figure 7 , the research indicated that most of the external wall materials [about 45\%] in these buildings are composed of brick. It was also established that there was no isolation in the walls of the building, which considerably increases the energy usage.

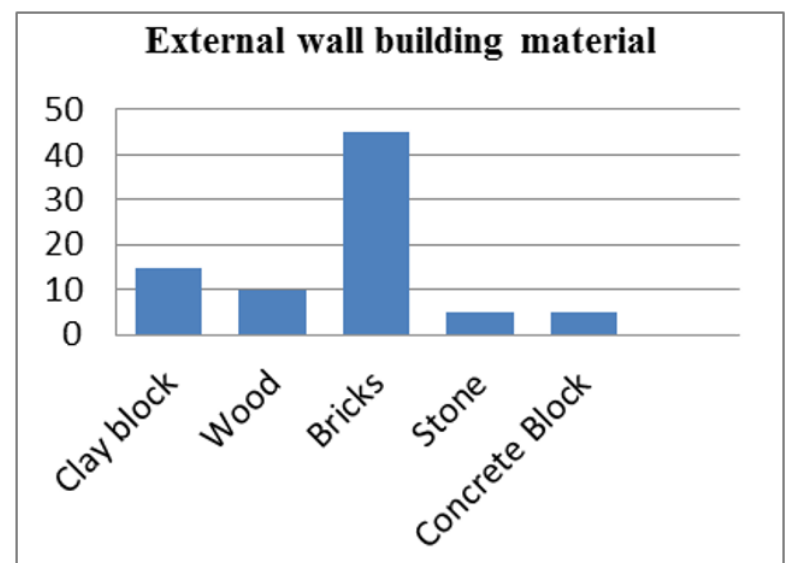

Figure 7. The above bar chart illustrates the external wall building material in the Karakol residential buildings.

From the perspective of embodied energy, brick provide good thermal mass, but it must be well insulated in order to avoid moisture collecting especially at the intersection point between the windows and the walls and in order to prevent heat transfer (Eco-housing Mainstreaming, 2009, p.3). In the research study it was also noted that the total energy consumption is primarily dependent on the conductivity value of the insulating materials in the walls.

\subsubsection{Wall thickness}

Figure 8 illustrates the effect of wall thickness on the energy consumption of these buildings. It was observed from the survey that all the buildings wall thicknesses are about $25 \mathrm{~cm}$ (60\%). It was also noted that the walls are not insulated and, therefore will not, store or retain energy in the external or internal spaces of these buildings following heating or cooling.

"Moisture in a building component always increases the transmission because the thermal conductivity of water is $0.6 \mathrm{~W} / \mathrm{MK}$. Normally present in the air in the form of water vapor, it infiltrates the insulation and owing to the temperature difference can condense there, which reduce the insulating effect and frost damage. So insulating materials should be protecting against moisture" (Hegger, et al., 2008, p.149).

\section{Exetrnal wall thickness}

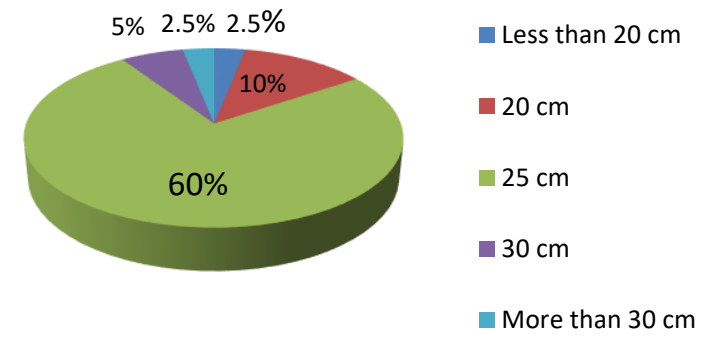

Figure 8. The above pie chart illustrates the external wall thickness in the Karakol residential buildings.

This indicates that wall thickness has little impact on the annual energy consumption. This suggests that building designers should focus on alternative strategies, some of which are contained in this research study, to achieve more significant reductions in the total energy consumption. Furthermore, incorporating thicker walls in the initial building design and planning stages would seem more appropriate than the saving in running cost due to the reduction in the overall energy use.

\subsection{Height of buildings}

The most significant things that the researcher observed about the buildings in the Karakol district is that in some of the buildings due to their poor orientation, height and distance between them only some parts of these buildings receive direct sun at noon, whilst others receive it during the morning and/or evening. Furthermore, and also as a result of dividing the building plan into four or more, only one side of the buildings gets the best wind for thermal comfort, which leads to a reduction of energy consumption in summer.

\subsection{Shading}

The researcher also observed that most of the buildings do not have any shading devices or awnings on the south façade and, consequently, the sun's rays enter these buildings directly at certain times in summer. As a result of this the apartments become too hot for the occupants and the air conditioning is required for cooling purposes which results in an increase in the energy costs.

\subsection{Construction details}

It was also discovered that the intersection points (window-wall, ceiling-wall) were influenced by moisture, which also leads to increases in heat transmission. 


\subsection{Roof construction}

The researcher also noted that the flat roof construction of these buildings, which also have no attic space, more readily permits the direct entry of the sun's rays into the building, which, in summer, creates an overheated living space, which is not at all appropriate for this hot-humid climate.

\subsection{Building regulation}

From the research carried out and as a result of an interview conducted with two professional architects who study environmental control and climatic design in Famagusta, it was established that there are no specific buildings regulations, codes or guidelines in this city in respect of building controls.

\section{Conclusions}

As a result, more than half of the energy consumption in the Karakol residential apartments is used for heating and cooling. It may be concluded from this research that the level of the consumption of the energy in this area is due to inappropriate design planning, such as the inordinate division of the floors in the apartments, which created the unfavorable orientation of some of the units. And also the use of improper, inappropriate building materials along with the lack of insulation, which, consequently, leads to increased energy demands and costs. Therefore, it is necessary to adapt the residential buildings in this area in order to minimize the passive, negative impacts of climatic factors on energy demand for heating and cooling.

From this study the research established that the planning and design process of residential apartments in a hot-humid climate, to ensure reduce energy consumption- should include a number of important factors. They are as follows:

1- In designing plans for residential apartments it is important to divide the floor in a way which permits the units to have both a north and south orientation, in order to achieve cross ventilation in summer and to have access to the sun's rays in winter.

2- If it is not possible to have cross ventilation in the apartments, the inclusion of a solar chimney is a good alternative method of circulating the air on all the floors on hot days (Eco-housing Mainstreaming, 2009, p.23).
3- In hot climates, thermal insulation should be used in the walls. Some of the suggested wall insulation types are mineral wool slabs, expanded/extruded polystyrene, or aerated concrete blocks (Eco-housing Mainstreaming, 2009, p.20).

4- Using awning on the south side of buildings in order to prevent the direct penetration of the sun's rays in summer.

5- Using sloped timber roofs with attic space and also thermal insulation materials under the roofs to insulate against the direct entry of the sun's rays, thus avoiding overheating in summer (Ozdeniz \& Hançer, 2005).

6- Using double or triple glazing with wooden frames and paying attention to the junction points between the window frames and the walls in these buildings is also essential.

In conclusion, therefore, if these suggested solutions are not incorporated by architects and construction companies in the design and planning of buildings in hot-humid climates in order to reduce the negative impact of such climates on buildings, it is necessary and important to introduce and establish building regulations or codes for both designers and building constructors to follow in order to produce buildings and living space appropriate for the hot-humid climate, as in the Karakol district of Northern Cyprus.

\section{Acknowledgments}

This research did not receive any specific grant from funding agencies in the public, commercial, or non-for-profit sectors.

\section{References}

Aksugur, E. (1996, August). Potential of passive cooling strategies in Cyprus. Paper presented at the Housing Research Conference, European Network in Housing Research, Helsingor, Denmark. Retrieved from ftp://193.140.174.222/, (used on 10 $10^{\text {th }}$ April, 2016).

Al-Homoud, M.S. (2005). Performance characteristics and practical applications of common building thermal insulation materials. Building and Environment, 40 (3), 353-366. https://doi.org/10.1016/i.buildenv.2004.05.0 $\underline{13}$

Coch, H. (1998). Bioclimatism in vernacular architecture. Renewable and Sustainable Energy Reviews, 2(1-2), 67-87. 
https://doi.org/10.1016/s1364-

$0321(98) 00012-4$

Dinsev, M. \& Mohd, M. (2004, April). Optimal building structural system selections for Famagusta. Paper presented at the International Gazimağusa symposium, Gazimagusa, North Cyprus. Retrieved from ftp://ftparch.emu.edu.tr/Projects/sempozyum, (used on 07 $7^{\text {th }}$ May, 2016). http://www.havvaalkanbala.com/StaticFile s/file/B-7 MED_i-TR_iOLOGY-KIBRIS.pdf

Eco-housing Mainstreaming. (2009). Building a better tomorrow: Passive architecture design system (annexure 3). India: Author. Retrieved

from http://www.ecohousingindia.org/, (used on 20th April, 2016). p. 3-23.

EIA. (1999). A look at residential energy consumption in 1997. Washington, DC. Retrieved

from

ftp://www.eia.doe.gov/pub/pdf/consumpti on/063297.pdf, (used on 15th April, 2017).

Galloway, T. (2004). Solar house: A guide for the solar designer. Burlington: Architectural Press. $\quad$ p. 18-182. https://trove.nla.gov.au/work/1 1430046? q\& versionld $=46574019$

Givoni, B. (1992). Comfort, climate analysis and building design guidelines. Energy and Buildings, $\quad 18 \quad$ (1), 11-23. https://doi.org/10.1016/0378-7788(92)90047$\underline{K}$

Givoni, B. (1994). Building design principles for hot humid regions. Renewable Energy, 5(58), 906-916. https://doi.org/10.1016/0960$1481(94) 90111-2$

Givoni, B. (1998). Climate consideration in building and urban design. New York: John $\begin{array}{llll}\text { Wiley \& Sons. } & 17 .\end{array}$ https://www.abebooks.com/booksearch/title/climate-considerationsbuilding-urban-design/author/givoni/

Hançer, P. (2005). Thermal insulations of roofs for warm climates (Unpublished master's thesis). Eastern Mediterranean University, Famagusta, North Cyprus. https://farc.emu.edu.tr/en/research/postgr advate-studies/phd-in-architecture

Hegger, \& Manfred, \& Fuchs, M., \& Stark, T., \& Zeumer, M. (2007). Energy Manual: Sustainable Architecture. Berlin, Germany. p. 91-149. https://www.amazon.com/Energy-ManualSustainable-ArchitectureConstruction/dp/3764388307
Indraganti, M. (2010). Thermal comfort in naturally ventilated apartments in summer: Findings from a field study in Hyderabad, India. Applied Energy, 87(3), 866-883. https://doi.org/10.1016/i.apenergy.2009.08. $\underline{042}$

Lapithis, P. (2004). Importance of passive solar design in Cyprus. Paper presented at the Proceedings ISES Conference, Orlando, USA. 6-10 th August 2005. Retrieved from http://unic.academia.edu/PetrosLapithis/Pap ers/367945/importance of passive solar desig n_for_cyprus, (used on $01^{\text {th }}$ June, 2017).

Landsberg, D., Stewart, R. (1980). Improving energy efficiency in buildings: $A$ management guide. Albany: State university of New York Press. p. 3- 31. https://searchworks.stanford.edu/view/8086 $\underline{72}$

Leskovar, V., \& Premrov, M. (2011). An approach in architectural design of energyefficient timber buildings with a focus on the optimal glazing size in the south-oriented façade. Energy and Buildings, 43(12), 34103418.

$$
\text { https://doi.org/10.1016/i.enbuild.2011.09.00 }
$$
$\underline{3}$

North Carolina Department of Commerce. (1999). Solar homes for North Carolina: A guide to building \&planning in solar homes. North Carolina: Solar Center. Retrieved from http://www.aliciaravettoarchitect.com/artic les/shnc2.pdf/2016.04.28, (used on 08 th May, 2016). p. 5-6.

Oktay, D. (2002). Design with the climate in housing environments: An analysis in Northern Cyprus. Building and Environment, 37(10), $\quad 1003 \quad$ - 1012. https://doi.org/10.1016/503601323(01)00086-5

Özdeniz, M., \& Hançer, P. (2005). Suitable roof constructions for warm climates Gazimag usa case. Energy and Buildings, $37(6)$, 643-649. https://doi.org/10.1016/j.enbuild.2004.09.00 $\underline{8}$

Smith, P. (2005). Architecture in a climate of change: A guide to sustainable design (2nd ed.). Burlington: Architectural Press. p. 69. https://epdf.tips/architecture-in-a-climateof-change.html

Thomas, D. (2002). Architecture and the urban environment: A vision for the new age. Woburn: Architectural Press. p. 156-158. https://www.google.com/url? $\mathrm{sa}=\dagger \& \mathrm{rct}=\mathrm{j} \& \mathrm{a}$ $=\& e s r c=s \& s o u r c e=w e b \& c d=2 \& c a d=r j a \& u a$ 
$\mathrm{ct=8 \& ved=2ahUKEwjm2fLRxb3fAhUIJVAKHT}$ AmB6cQFjABegQICRAC\&url=http\%3A\%2F\% 2Fwww.ndri.ir\%2FSites\%2FFiles\%2F620\%2FArc hitecture\%2520and\%2520the\%2520Urban\%2 520Environment\%2520A\%2520Vision\%2520fo r\%2520the\%2520New\%2520Age.pdf\&usg=A OvVaw3yHkR5yt2a2m2pL9VIMpdU

Tsilingiris, P.T. (2002). On the transient thermal behavior of structural walls- the combined effect of time varying solar radiation and ambient temperature. Renewable Energy, 27(2), 319-336.

https://doi.org/10.1016/s0960$1481(01) 00167-7$

URL1, Word weather and climate information. (2009). Average minimum and maximum temperature over the year. Retrieved from http://www. weather-and-

climate.com/average-monthly-RainfallTemperature-Sunshine ,Famagusta,Cyprus, (used on 01 th April, 2017).

URL2, Google maps. (2016). karakuls, Famagusta, Cyprus. Retrieved from http://maps.google.com/maps?hl=en\&q=k arakol+famagusta\&bav=on.2,or.r gc.r pw.r af.,cf.osb\&biw $=1440 \&$ bih $=756 \& u m=1$ \&ie $=U$ TF-8\&sa $=N \& t a b=W l$, (used on $01^{\text {th }}$ April, 2016).

Watson, D. \& Labs, K. (1983). Climatic buildings design: energy-efficient building principles and practice. New York, United State of America: McGraw-Hill. $\quad$ p. 171. https://www.academia.edu/14665063/Bibli ograf\%C3\%ADa_y referencias Confort T\%C3\%A9rmico en Bioclima Semi

Fr\%C3\%ADo Estimaci\%C3\%B3n a partir de Llos_Enfoques_de Estudio_Adaptativo_y_Pr edictivo

Zain, Z., \& Taib, M., \& Shah Baki, S. (2007). Hot and humid climate: Prospect for thermal comfort in residential building. Desalination, 209(1-3),

261-268. https://doi.org/10.1016/i.desal.2007.04.036 